Left: POLITICAL SCIENCE QUARTERLY

Right: CHINA’S FOREIGN POLICY CRISIS BEHAVIOR

\title{
Power and Risk in Foreign Policy: Understanding China's Crisis Behavior
}

KAI HE

Along with China’s rise in military and economic capabilities, foreign policy crises involving China seem more likely, as seen in the diplomatic standoffs in the South China Sea and over the Diaoyu/Senkaku Islands. With the United States “rebalancing toward Asia,” diplomatic and military crises between China and its neighbors will inevitably involve U.S. interests in the AsiaPacific. ${ }^{1}$ Therefore, it is imperative for policymakers in the United States and other nations to understand China’s dynamic behavior in foreign policy crises—-that is, when China will take risks to escalate a crisis and when China will avoid risks to seek accommodation during a crisis.

Borrowing insights from prospect theory—a Nobel Prize-winning behavioral psychology theory_-I introduce a “political survival prospect” model to shed some light on China’s dynamic behavior during crises. I suggest that Chinese foreign policy crisis behavior is shaped by Chinese decision makers' prospects regarding their political survival status: (1) when Chinese leaders are framed in a domain of losses or their political survival is at stake, then a risk-acceptant behavior in the form of coercive diplomacy is more likely to be adopted; (2) when Chinese leaders are framed in a domain of gains, then a risk-averse behavior in the form of an accommodative policy is more likely to be chosen.

This article begins with a review of the "state of the art” in the study of China's crisis behavior and introduces the political survival prospect model as an alternative approach to 
understand the variations in China's crisis behavior. Then, two foreign policy crises that China experienced during Hu Jintao's leadership will be examined: the 2009 Impeccable incident between China and the United States and the 2010 "boat collision” crisis between China and Japan. In conclusion, I suggest that the Chinese leadership under Xi Jinping might be risk acceptant in future crises if $\mathrm{Xi}$ is cornered into a vulnerable situation. Therefore, the United States and other nations should be careful how they are shaping the domains of action for Chinese leaders during crises.

\section{CHINA'S FOREIGN POLICY CRISIS BEHAVIOR: RATIONAL, IDIOSYNCRATIC, OR SITUATIONAL?}

In the international relations literature, a foreign policy crisis is defined by three factors: (1) “a threat to one or more basic values," (2) "an awareness of finite time for response to the value threat,” and (3) "a heightened probability of involvement in military hostilities.”2 Some scholars introduce the concept of "near crisis" by relaxing the requirement for the possibility of involvement in military hostilities. ${ }^{3}$ A near crisis refers to a diplomatic conflict or tension between two nations that approaches the intensity of a military crisis but has a relatively low possibility of military hostility.

\section{The Study of China's Foreign Policy Crises after the Cold War}

I focus on the near crisis cases between China and other nations for three reasons. First, China has not engaged in any violent military conflicts with other states since the end of the Cold War. However, China has been involved in some military-oriented near crises, such as the 1999 embassy bombing in Yugoslavia and the 2001 EP-3 incident. It is worth noting that scholars may 
not reach a consensus on how to define a crisis in the study of Chinese foreign policy behavior. However, as Andrew Scobell and Larry Wortzel point out, "the study of China's behavior in conditions of tension and stress ... is of considerable importance to policymakers and analysts around the world."4 This research intends to shed some light on patterns of Chinese behavior in near crises or crisis-like situations.

Second, although the possibility of military conflict from these near crises is low by definition, they could easily escalate to real military conflicts, especially if policymakers do not manage them well. The possible unintended consequences of these near crises would actually loom larger than the actual crises. Finally, these near crises are usually accompanied by a spiral of distrust and tension as a result of a lack of information and communication among the parties involved. On the current South China Sea disputes between China and its neighbors, which may not lead to immediate military conflicts, the International Crisis Group reports that "all of the trends (sovereignty disputes) are in the wrong direction, and prospects of resolution are diminishing.” 5 This worsened crisis management pattern has not only strained relations between China and other Asian countries but also put regional security and stability at stake.

The existing scholarly work on China's near crises is mainly descriptive in nature, focusing on unique characteristics of China’s crisis behavior, emphasizing responsibilities instead of interests, seeking guidance from China's political tradition instead of a legal solution, and lacking a crisis management mechanism. ${ }^{6}$ One collaborative research project on U.S.-China crisis behavior is worth noting. The Carnegie Endowment for International Peace and the China Foundation for International and Strategic Studies conducted a collaborative research project on U.S.-China crisis management in $2004 .^{7}$ However, the problem with this research lies in the “comprehensiveness” of the project. On the one hand, it identifies six sets of variables that 
influence U.S. and Chinese crisis behavior, including elite perceptions and beliefs, domestic politics and public opinion, decision-making structure and process, information and intelligence receipt and processing, international environment, and idiosyncratic or special features. ${ }^{8}$ On the other hand, the project fails to specify which variable or variables play the most important role in shaping U.S. and Chinese foreign policy crisis behavior. It is politically necessary to present the sets of variables in order to achieve the purpose of providing recommendations to both governments on how to cope with future foreign policy crises. However, this list of variables fails to capture the dynamics of China's crisis behavior, that is, under what conditions and why China (or the United States, which is not covered given this article's scope) has adopted more coercive policies in some crises but more accommodative diplomacy in others.

\section{The Rationalist Approach: Are All Decisions Rational?}

Rationalism is the prevailing approach in the study of China's foreign policy crisis behavior. It assumes that during crises policymakers are rational in making decisions to either escalate or deescalate conflict. For example, Thomas Christensen suggests that both Mao Zedong and Harry S. Truman used the Korean War to advance their domestic political agendas. ${ }^{9}$ This school of thought sometimes attributes the escalation of conflicts to either an "information" problem or asymmetric power relations. First, because of incomplete information during crises, China and its adversaries sometimes are entrapped in unnecessary conflicts. For example, in his classic work on the Korean War, Allen Whiting suggests that the United States misread or underestimated China's signaling of its resolve during the Korean War because of the absence of credible, private, and consistent lines of communication, which indirectly triggered the escalation of conflicts between the two nations. ${ }^{10}$ 
Second, the power discrepancy between a triggering state and a target state also determines whether a crisis will turn violent. For example, Michael Brecher and Jonathan Wilkenfeld point out that a crisis triggered by a weaker power is less likely to lead to a military conflict because "the target state need not necessarily employ violence in order to achieve its crisis objectives." ${ }^{\text {11 }}$ In other words, it is not rational for a stronger state to deal militarily with a crisis triggered by a weaker state because the stronger state has other means, such as economic sanctions, to retaliate against the weaker adversary. Based on this rationalist approach, Wang Jisi and Xu Hui argue that the power discrepancy between China and the United States explains why the three Taiwan crises $(1955,1958$, and 1996) did not cause military conflicts between the two nations. $^{12}$

Another example is the "audience cost" argument suggested by Jessica Chen Weiss in explaining China's different policies toward anti-American protests during crises. ${ }^{13}$ Weiss argues that the Chinese government can use domestic anti-American protests as an audience cost mechanism to either signal its resolve or convey its commitment to cooperation to the United States. In case studies, Weiss suggests that the reason China allowed protests during the 1999 embassy bombing incident was to demonstrate its resolve that "China could not be bullied." During the 2001 EP-3 incident, the Chinese government stifled nationalist protests because of a “desire to reassure the New Bush administration.”14

This rational choice approach faces two problems in analyzing China's foreign policy crisis behavior. The first is the assumption of rationality. It is analytically convenient but flawed in practice. Because of the constraints of incomplete information, cognitive bias, and urgency for making decisions, policymakers may not be able to make so-called rational decisions, that is, decisions based on a sophisticated calculation of costs, benefits, and their probabilities regarding 
a certain policy during a crisis. Instead, policymakers sometimes have to make decisions in a domain of bounded rationality, which is beyond the explanatory power of the classic rational choice approach. $^{15}$

Analyzing the three Taiwan crises, Wang and $\mathrm{Xu}$ are correct to argue that the huge power discrepancy helped both nations avoid large-scale military conflicts. However, why a weaker China intended to trigger the crises across the Taiwan Strait against a stronger United States is still an unanswered question for the rational choice approach. Weiss’s autocratic signaling through domestic protests is indeed interesting. However, why Chinese leaders wanted to signal their tough resolve only in the embassy bombing crisis, but not in the EP-3 incident, is not clear. Both crises involved Chinese casualties and violations of Chinese sovereignty. If Chinese leaders were rational and their definitions of interests were fixed, as rational choice scholars assume, they should have behaved similarly in these two crises. However, this is not the case. The major problem with this rationalist approach is the presumed state interest, which is not fixed but is constituted by situation, emotion, and other ideational factors in practice. Unfortunately, rational choice theory does not have a theory of interests.

Second, the policy recommendation to improve communication channels and clarify signaling during crises is politically appealing but practically problematic. Undoubtedly, through good signaling and smooth communication, China and the United States can avoid unnecessary conflicts and possible escalation of a crisis. However, because of the conflictual nature of crises, both parties have incentives to hide their bottom lines and exaggerate their resolve and capabilities in order to maximize their bargaining positions during crises. ${ }^{16}$ Therefore, improving the understanding of signaling and communication alone cannot fundamentally reduce the possibility of escalation during a crisis. 
For example, regarding the 2001 EP-3 incident, some U.S. scholars argue that early escalation of the incident was mainly a result of the slow responses of the Chinese government to U.S. requests. ${ }^{17}$ However, a prevailing explanation in China is that a rushed decision by the U.S. Pacific Command to publicize the incident "made a solution through quiet diplomacy impossible." ${ }^{\text {18 }}$ Both China's slow response and the United States' rushed decision are seemingly rational: China wanted more time to conduct initial investigations of the incident, while the U.S. Pacific Command needed to ensure the safety of the crew and the EP-3 plane as soon as possible. If this is the case, then the early escalation of the EP-3 incident seems inevitable, even though the communication channel has no problem.

\section{The Cultural Approach: Too Indeterminate}

Contrary to the rationalist approach, another school of scholars study China's crisis behavior from a cultural perspective, emphasizing a unique or idiosyncratic understanding of China's behavior during crises. For example, Wang and Xu suggest that China’s foreign policy crisis behavior is shaped by a "more sophisticated political tradition, a longer history, and a prouder civilization.” In particular, Wang and Xu point out that the major guideline of China’s crisis strategy originated from Mao Zedong’s war experience against Japan and the Chinese Nationalist Party. The three principles of the guideline—“on just grounds, to our advantage, and with restraint” (youli, youli, youjie)—are rooted in Chinese culture and tradition, which emphasize morality over interest, self-defense over offense, and restraint over provocation. ${ }^{19}$ In contrast, Alastair Iain Johnston suggests that Chinese leaders prefer offensive military approaches during crises because of the influence of China's Realpolitik strategic culture. Therefore, China 
sometimes adopts coercive diplomacy or even a preemptive attack to show its resolve and seize

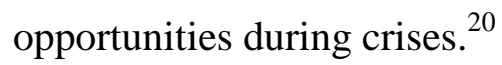

The cultural approach faces two major problems. First, it is indeterminate in nature. It is still unsettled among scholars and policymakers whether Chinese culture is offensive or defensive, especially during crises. In some cases, especially during the Cold War, China’s crisis behavior was offensive, as seen in the two Taiwan Strait crises during the 1950s. However, in other cases, especially after the Cold War, China’s policy during crises was mostly defensive in orientation, such as in the 1999 embassy bombing incident and the 2001 EP-3 incident. It is difficult to attribute the variations in China's crisis behavior across time simply to Chinese culture.

Another problem with the cultural approach lies in China’s emerging pluralistic decisionmaking mechanism. The cultural approach may be able to explain China’s crisis behavior under strong leaders, such as Mao Zedong and Deng Xiaoping, who not only played decisive roles during crises but also possessed distinctive and dominant cultural beliefs and characteristics. However, it is obvious that China's decision-making process is approaching pluralism because of the lack of strong leaders with revolutionary backgrounds and charisma since the Cold War. ${ }^{21}$ The idiosyncratic predictions of China's crisis behavior by cultural theorists, therefore, are no longer compatible given the sea changes in Chinese leadership style and decision-making structure.

\section{A Prospect Theory Approach: Situational Choices}

To better understand Chinese crisis behavior and to address the weaknesses of the rationalist and cultural approaches, I introduce a situational approach-based on prospect theory in behavioral 
psychology—to shed some light on the study of China's foreign policy crisis behavior. From laboratory experiments, Daniel Kahneman and Amos Tversky, the originators of prospect theory, found that the way people interpret their situation for making choices—as a domain of either gains or losses-influences how they behave in terms of their risk orientation. ${ }^{22}$ People tend to evaluate choices with respect to a reference point; they choose risk-averse behavior in a domain of gains but risk-acceptant behavior in a domain of losses. In other words, if people are in an advantageous situation (a domain of gains), they are more likely to behave cautiously (be risk averse) to protect their gains and avoid losses. However, when people are in a disadvantageous situation (a domain of losses), they are more likely to choose risky behavior (be risk acceptant) that may either reverse or worsen their losses. ${ }^{23}$ In other words, they choose irrationally by going "against the odds" of expected utility calculations, as in the case of the debt-ridden lottery player in the domain of losses whose odds (probability) of winning the lottery (achieving gains) are much worse than losing the purchase price (incurring losses) of the lottery ticket. ${ }^{24}$

Prospect theory can provide an alternative account of political decisions taken under risk by replacing the indeterminacy of a cultural approach with a more deterministic situational approach and by replacing the invariant expected utility assumption of a rational choice approach in the study of crisis behavior. Rational choice approaches often make an "as if" assumption about people's optimal rationality to account for policymakers' decisions and a state’s policy choices. ${ }^{25}$ However, contrary to what rational choice theorists assume, numerous empirical anomalies in both everyday life and high politics indicate that people do not always behave as if they are rational. ${ }^{26}$

Foreign policy crises normally take place under conditions of relatively high uncertainty and complexity, thereby involving high levels of risk in the form of probable losses. The high 
level of uncertainty and risk sometimes influences and even distorts policymakers’ preferences. Challenging the "as if" assumption of rational choice approaches, prospect theory provides a systematic way to explain and predict decisions under risk without prior knowledge about individual preferences. By examining the different situations (domains of action) in which people make decisions, prospect theory explains and predicts risk propensities as well as preferences and choices. It also transcends the local idiosyncrasies of beliefs and norms associated with the cultural approach. Although prospect theory was based initially on classroom experiments, its findings have been tested and confirmed by many scholars in the fields of economics, business, management, finance, and political science. In the study of foreign policy, recent scholarship on prospect theory has been promising. ${ }^{27}$

\section{A POLITICAL SURVIVAL PROSPECT MODEL OF CRISIS BEHAVIOR}

Before we apply prospect theory to the study of crisis behavior, we need to define the risk propensities of different crisis behaviors. The crisis management literature introduces two types of behavior during crises: coercion and accommodation. ${ }^{28}$ The purpose of coercion is to escalate the crisis for the desired political and military goals, which a state may not be able to get otherwise. Accommodative behavior, on the contrary, aims to de-escalate conflicts for reconciliation with opponents during crises. In terms of risk propensity, coercion involves more risks than accommodation because the former is more likely to trigger military conflicts than the latter. Therefore, I suggest that coercion can escalate a crisis and is a risk-acceptant policy with respect to the danger of military conflicts. On the other hand, accommodation can de-escalate a crisis and is a risk-averse behavior. In order to explain when a state is more likely to choose a 
coercive or an accommodative policy option, we need to set the reference point for defining the domain of actions of policymakers during crises.

One major challenge for applying prospect theory to real-life political events is how to set the reference point. Because there is no theory of framing or setting the reference point, scholars have introduced different techniques to pragmatically set a reference point for determining an actor's domain of gains or losses. ${ }^{29}$ As Jonathan Mercer suggests, there are five prevailing methods or reference points: the status quo, aspiration level, heuristics, analogies, and emotions. ${ }^{30}$ I choose the status quo as the reference point to determine a domain of actions for decision makers. How the status quo situation for political leaders is determined is beyond the theoretical scope of prospect theory. As an experiment-based theory of decision under risk, prospect theory cannot directly apply to politics without a political theory to help identify what the status quo is as the reference point in the framework.

Borrowing insights from comparative politics, I use the status quo of the leader's political survival to define the reference point, as political survival is the most important concern for all political leaders. ${ }^{31}$ Because decision makers face tremendous pressure from both international and domestic arenas during a foreign policy crisis, I suggest two general factors that can influence leaders’ perceptions of their political survival status during crises. One is leadership authority, and the other is international pressure. Leadership authority refers to a leader's capability to secure political support from domestic actors. In a democratic system, domestic power strength can be measured by the relationship between the executive branch and the legislature (either parliament or congress), as well as the public approval rate for the leader.

For example, if the executive branch can get full support from the legislature, the top decision makers will be able to execute policy decisions more forcefully and effectively. If the 
executive branch is constrained by the legislature or public opinion, the top decision makers will be in a "lame duck" situation. In an authoritarian regime, although the decision-making system is more concentrated, the top leaders still need to consider the domestic "selectorate" or "winning coalition," such as the military and the bureaucracy, in making decisions. ${ }^{32}$ Leadership authority in an authoritarian regime is largely shaped by the relationship between the top leaders and the domestic interest groups, such as the military and the party.

International challenges and pressure can also have an impact on top leaders' political survival status. International challenges can be measured by the relationship between a state and the major powers in the system. Although political leaders' political legitimacy is mainly based on domestic constituency in a democracy or domestic support from key interest groups in authoritarian regimes, how well they handle an international challenge is also crucial for their political survival at home. For a democratic leader, a successful foreign policy may not be the determining factor for winning a general election, as seen in George H.W. Bush’s electoral defeat in 1992. However, a failed foreign policy will definitely hurt the leader's political credibility and accountability at home, as the Iran hostage crisis did to President Jimmy Carter.

In an authoritarian regime, foreign policy becomes an even more important factor affecting the top leaders' political survival. On the one hand, some authoritarian leaders need international support to sustain their power domestically. As Steven David suggests, many political leaders in Third World countries during the Cold War relied on their international military allies to balance their domestic opponents and to strengthen their political legitimacy at home. ${ }^{33}$ On the other hand, successful handling of international challenges can boost an authoritarian leader’s political credit at home. Fidel Castro, Hugo Chávez, and Vladimir Putin are all famous for their tough stands against Western pressure at home, and their political 
legitimacy partly stems from their anti-Western ideologies and policies. However, this is not to suggest that all authoritarian leaders are hostile toward the outside world. No authoritarian leader wants to face political challenges from the outside because one failure in handling international pressure may terminate the regime, as we can see from the fall of Suharto in Indonesia, Hosni Mubarak in Egypt, and Muammar el-Qaddafi in Libya.

The severity of the crisis is the third factor that is unique in a crisis situation. The more severe a crisis is, the more constraints policymakers will face in coping with the crisis. Here, the severity of the crisis can be measured in both physical and ideational ways. On the one hand, the loss of lives during a crisis will put more pressure on policymakers than just financial costs. On the other hand, some emotional and psychological factors, such as nationalism and a sense of betrayal, may drive decision makers into a corner as well.

By focusing on leaders' political survival status, prospect theory can help us link the domain of actions with risk-laden policy choices and generate the following two hypotheses:

Hypothesis 1: If political leaders' political survival is framed in a domain of gains, they are more likely to behave in an accommodative way, that is, to choose risk-averse policies during crises.

Hypotheses 2: If political leaders' political survival is framed in a domain of losses, they are more likely to behave in a coercive way, that is, to choose risk-acceptant policies during crises.

In the following section, I perform a congruence test of these hypotheses by analyzing China's two foreign policy crises under Hu Jintao: the 2009 Impeccable incident between China and the United States and the 2010 boat collision crisis between China and Japan. For the congruence test, I will first briefly introduce the crises and identify at least two policy options- 
risk averse versus risk acceptant—for President Hu Jintao. Then I examine Hu's domain of action during the crises. Based on the political survival prospect model, I predict what Hu should have done during crises. In the last step, I compare the model's predictions with China's real policy choices to see whether they are congruent.

There are three reasons why I selected the two crises under Hu for this research. First, the two crises can serve as a within-case comparison design through which we can examine how and why Hu made different decisions in the two crises. The advantage of within-case comparison is to control many variables under Hu's leadership, such as Hu's personality, ideology, and even bureaucratic politics. In other words, we can single out the impacts of international pressure and leadership authority on Hu's crisis behavior in this research.

Second, although $\mathrm{Hu}$ is no longer in power, his patterns of behavior during crises are still the best reference for us to understand how Xi Jinping—the Chinese leader since 2012—will behave during future crises. Because of the opaque nature of the Chinese one-party regime, it is hard for scholars to grasp how Chinese leaders make foreign policy decisions, especially during crises. Challenging the conventional rationalist and cultural approaches, prospect theory offers a novel, situation-based explanation of Chinese behavior during crises. Although his leadership style and personality differ significantly from Hu's, Xi still faces a similar or even the same political structure and international environment that Hu did. By examining the challenges and constraints that Hu experienced during the two crises in this research, we can reach a better understanding how Xi may behave when facing the same situation.

Last but not least, the major purpose of the case study is to provide a "plausibility probe" in the study of Chinese leaders' decision making during crises. Based on prospect theory, I suggest a political survival prospect model to explain when Chinese leaders will take risks to 
escalate a crisis and when they will not. The two crises under Hu’s leadership are examined as a first empirical test of the model. If the model passes the test, other scholars will be encouraged to conduct more rigorous tests of the model on other cases, including future crises under Xi. This is not to suggest that the prospect theory-based model is the right explanation of Chinese leaders' decision making during crises. Instead, this study offers a new theoretical angle to enrich our understanding of Chinese behavior during crises.

It should be noted that the political survival prospect model focuses mainly on leaders’ political fortunes rather than regime security because prospect theory is an individual-based theory. In examining China’s cooperative or compromising behavior in territorial disputes after the Cold War, M. Taylor Fravel introduces an innovative “diversionary peace” theory, which suggests that a weak communist regime and domestic strife are the major reasons for China to compromise in its territorial disputes since the Cold War. ${ }^{34}$ My model differs from Fravel's regime insecurity theory in two ways. First, I focus on Hu’s political survival status rather than the communist regime’s security, although these two are intertwined. I suggest that as the top leader in the Chinese Communist Party (CCP), Hu made the final decision during crises. Depending on the stakes for Hu's political survival during crises - that is, whether he was framed in a domain of gains or losses - Hu made either risk-acceptant or risk-averse decisions. Second, my model can account for both the conflictual and cooperative policies of China during foreign policy crises, whereas Fravel's model mainly discusses China's cooperation in territorial disputes.

\section{CHINA'S CRISIS BEHAVIORS: WHEN TO COERCE AND WHEN TO}

\section{ACCOMMODATE?}




\section{Case 1: The 2009 Impeccable Incident}

On 9 March 2009, the U.S. Pentagon issued a statement complaining that five Chinese ships had “shadowed and aggressively maneuvered in dangerously close proximity" to the USNS Impeccable, an unarmed ocean surveillance vessel, during routine operations in the South China Sea about 75 miles south of China's Hainan Island on 8 March. ${ }^{35}$ According to the Pentagon report, the Chinese ships belonged to Chinese Naval Intelligence, the Bureau of Maritime Fisheries, and the State Oceanographic Administration; there were also two small trawlers. Two of the Chinese vessels approached the Impeccable within 50 feet, waved Chinese flags, and asked the U.S. ship to leave the area. The Impeccable responded by spraying one of the vessels with fire hoses. Later, when the Impeccable started to leave the area, the Chinese vessels dropped pieces of wood in the water, which forced the Impeccable to make emergency turns in order to avoid collision. The Pentagon spokesman called the incident "one of the most aggressive actions we’ve seen in some time."36

The U.S. Embassy in Beijing lodged a formal protest with the Chinese government. In addition, U.S. defense officials reiterated the protest to China's defense attaché in Washington, DC. On 10 March, a Chinese Foreign Ministry spokesman stated that the U.S. complaint about the Impeccable incident was "totally unacceptable to China," as the Impeccable had "violated the international and Chinese law” by conducting intelligence data gathering in China’s 200nautical-mile Exclusive Economic Zone (EEZ). ${ }^{37}$ As a U.S. naval surveillance vessel, the Impeccable is designed to map the ocean floor with passive and active low-frequency sonar arrays. The information gathered by the sonar system can be used by the U.S. Navy to detect and track other nations’ submarines. It is reported that China has a secret submarine base on Hainan 
Island, which is why the surveillance activities of the Impeccable were regarded as highly sensitive.

As one Chinese scholar points out, the Impeccable incident "constitute[d] the most serious friction between China and the United States” since the EP-3 midair collision incident in $2001{ }^{38}$ It is still not clear whether China's top decision makers were directly involved in the interception activities by Chinese ships during the Impeccable incident. It might have been a normal activity by the Chinese military to counter U.S. surveillance and intelligence gathering in China's EEZ. The Pentagon reports stressed that the Impeccable incident was not an isolated event: “The Impeccable and another ocean surveillance ship have been targeted five times in the past week [before the Impeccable incident on 8 March]."39 On the Chinese side, it came as a "big surprise" when the United States publicized the incident because it seemed like routine "spying and counter-spying” activity between the United States and China in the South China Sea, as in recent years. ${ }^{40}$

However, after the Pentagon lodged an official protest with the Chinese Foreign Ministry, the incident became a foreign policy crisis that had the potential to disrupt bilateral relations. It was time for China's top decision makers to become involved in dealing with the crisis. As China's top decision maker, Hu had two options. First, Hu could ignore the U.S. complaints and continue the interception to counter U.S. surveillance activities in China's EEZ. Second, Hu could stop or constrain the actions of interception against U.S. surveillance activities in order to avoid further escalation of the crisis. The first option is coercive in nature because it signals China's resolve in countering U.S. surveillance in the EEZ. ${ }^{41}$ The second option is an accommodation policy, which could alleviate the military tension between China and the United States caused by the incident. Comparing these two options, the first coercive action is a risk- 
taking or risk-acceptant decision because it may escalate future military conflicts between the two nations. The accommodation policy is a risk-avoidance policy because it signals China's willingness to back down from its previous position against U.S. surveillance in its EEZ.

Hu's domain of action: Everything is getting right. The political survival prospect model suggests that a political leader's domain of action is shaped by both international and domestic factors. First, we need to evaluate the nature of the crisis. Although the United States filed serious complaints about the precarious "harassments" of the five Chinese vessels toward the Impeccable, there were no casualties. Compared to other foreign policy crises that China had experienced since the Cold War, such as the 1999 embassy bombing incident and the EP-3 incident, the Impeccable incident was one crisis in which China was not a victim but an initiator. Although the interceptions by ships and fighters could not stop the U.S. reconnaissance activities, the major purpose of China’s “harassments” was to signal China’s resolve to counter “aggressive” U.S. conduct. Unlike the military encounters between Chinese submarines and U.S. warships in 1994 and 2006 in the Yellow Sea, there was no military confrontation in the Impeccable incident. ${ }^{42}$ Therefore, the severity of the Impeccable incident was relatively low. It was a well-prepared, semimilitary action of China against increased U.S. surveillance activities in the EEZ.

Domestically, Hu started to take power as general secretary of the CCP in 2002. However, Hu's power consolidation inside the CCP was not smooth given the reluctant retirement of Jiang Zemin. Hu did not take over the post of chairman of the Central Military Committee until 2004. However, Hu gradually consolidated his power in 2007, during his second term as general secretary of the CCP, at the 17th Party Congress. In 2006, Hu had strengthened his power base in the military by promoting 10 full generals. ${ }^{43}$ In the fall of 2006, Hu had also successfully 
removed Chen Liangyu, the party secretary of Shanghai and a Politburo member closely associated with Jiang’s “Shanghai Gang.” ${ }^{44}$ Chen Liangyu was the highest-ranking party official to be arrested since Jiang removed Chen Xitong, Jiang's political rival and then party secretary of Beijing, in 1996. Ironically, both Chen Liangyu and Chen Xitong were charged with corruption. Just as Chen Xitong's removal had signified a political victory for Jiang 10 years earlier, Chen Liangyu's arrest indicated Hu's success in fighting Shanghai Gang led by Jiang. It is reported that Jiang personally endorsed Chen Liangyu's removal. However, it is also suggested that Jiang was under tremendous pressure from Hu because Jiang's son, who used to do business in Shanghai, was allegedly involved in Chen’s scandal.

At the 17th Party Congress in 2007, Zeng Qinghong, Jiang's close associate and a member of the Shanghai Gang, was forced to retire because he had reached the age limit of 68 set for party leaders. It was another political blow to Jiang. Although there were still at least four members of the 2007 Politburo Standing Committee associated with Jiang, Hu faced fewer constraints and challenges from the Shanghai Gang during his second term than during his first. Another indicator of Hu's consolidation of authority was the incorporation of his "scientific development concept” into the revised party constitution. Differing from Jiang's "GDPcentered" policy, Hu launched his new "people-centered” developmental model in 2003. It was later named the scientific development concept, emphasizing the importance of social justice in building a "harmonious society."

Just as Jiang’s “Three Represents” idea was included in the party constitution in 2002, Hu's scientific development concept became his ideological contribution to the CCP. Compared to Jiang, who required more than 10 years to put a stamp on China's political system, Hu spent only five years achieving the same goal. It symbolized a great political success for Hu. When the 
Impeccable incident occurred in early 2009, Hu's political authority inside the party was getting stronger, especially after his political victory against the Shanghai Gang. The international pressure that Hu faced was also relatively low when the Impeccable incident occurred because of China's rising image as a result of the Olympic Games, the country's strong economic power during the world economic recession, and improved U.S.-China relations. In 2008, Beijing successfully hosted the Summer Olympic Games, which was seen as a sign of China's renaissance on the world stage.

In late 2008, the global recession lifted China's status as an economic powerhouse in the world. Although China's economy slowed to a 9 percent growth rate in 2008, it was still the most dynamic economy in the world. In addition, the Chinese government announced a two-year, 4 trillion Chinese yuan (US\$586 billion) stimulus plan to beef up its economy. It was the largest economic stimulus plan ever undertaken by the central government. As Dominique Strauss-Kahn, managing director of the International Monetary Fund, pointed out, "it's a huge package . . . It will have an influence not only on the world economy in supporting demand but also a lot of influence on the Chinese economy itself, and I think it is good news for correcting imbalances." ${ }^{45}$ It is fair to say that by the end of 2008 and early 2009, China was regarded as the hope of economic recovery in the world.

In 2009, President Barack Obama entered the White House. Unlike other new presidents who normally took on China at the beginning of their term, which is called the "new president syndrome,” Obama showed a smiling face toward China. ${ }^{46}$ In February, U.S. Secretary of State Hillary Clinton visited Beijing and gave a speech about "tackling the difficulties in the same boat” with China. The United States and China also established an institutionalized dialogue mechanism, the U.S.-China Strategic Dialogue, which covered issues ranging from the economy 
to security. In addition, the two countries started to discuss resuming military contacts, which had been suspended after U.S. arms sales to Taiwan in 2007. To the disappointment of human rights groups, Secretary Clinton downplayed China’s human rights issue during her visit, treating it as "not significant." ${ }^{47}$ Apparently, overall economic interests won out over liberal ideology in America's strategic calculations toward China.

In sum, Hu was placed in a domain of gains when the Impeccable incident took place. For China in general and for Hu in particular, 2008 had featured great success and glory. This does not mean that Hu did not face domestic and international challenges. However, relatively speaking, it seems that everything was under control and everything was getting better for Hu. Hu's policy choice: External accommodation and internal antihegemon campaign. It is not clear whether Hu was informed of the Chinese vessels' interception actions before the Impeccable incident. From the frequent interceptions of Chinese vessels against U.S. surveillance ships, it is possible to infer that these actions may have been routine maneuvers directed by the local military authority. However, when the Pentagon publicized the incident, $\mathrm{Hu}$ started to get involved in making decisions as to how to settle the crisis. Because Hu was framed in a domain of gains, the political survival prospect model suggests an accommodation policy for Hu to avoid further risks. The risk here refers to the possibility of military conflict with the United States in the case of further escalation of the crisis. Hu's actual policy was to externally accommodate U.S. surveillance, but with an internal twist of an antihegemon campaign to appease the domestic audience.

After the Impeccable incident, Chinese foreign minister Yang Jiechi visited Washington, preparing for the first meeting between $\mathrm{Hu}$ and Obama on the margins of the G-20 summit in London on April 1. It seems that the timing of the incident did not fit the cooperative and 
favorable atmosphere between the United States and China. Clinton had just conducted her first "smiling” diplomacy in Beijing less than one month before. Yang’s scheduled visit on March 11 was intended to create a positive setting for Hu and Obama's first meeting in London. Therefore, the top leaders in both countries did not want the incident to change the cooperative course between the two nations. When Secretary Clinton raised U.S. concerns about the Impeccable incident, Yang agreed to "work to ensure that such incidents do not happen again in the future." In addition, Yang also met with President Obama and National Security Adviser James Jones during his visit. Later, the White House press release noted that Obama had stressed the importance of military-to-military dialogue in order to avoid future incidents. ${ }^{48}$

In Beijing, China's attitude toward the United States differed significantly from its attitude toward the domestic audience. Externally, China downgraded the impact of the incident on U.S.-China relations. For example, Zhang Deshun, a rear admiral in the Chinese navy, stated that "the incident ... is not going to stop anything." He reiterated an invitation to the United States to watch a Chinese naval parade off the eastern port of Qingdao in April. ${ }^{49}$ Internally, China initiated an antihegemon propaganda campaign against U.S. surveillance in China's EEZ. Chinese media portrayed the Impeccable incident as an example of U.S. hegemonic bullying against China and charged the United States with violating international law. ${ }^{50}$

China’s antihegemon campaign after the Impeccable incident served two purposes. On the one hand, it justified the Chinese government's legal position during the crisis to the domestic public. Although it by no means directly challenged the United States, it showed China's “uncompromising” policy toward the United States. On the other hand, the media campaign promoted patriotic sentiments in society, which strengthened the political legitimacy 
of the communist regime. It should be noted that China's domestic antihegemon campaign after the incident was isolated from its external policy of dealing with U.S. surveillance.

On 12 March, four days after the incident, the United States announced the dispatch of a guided-missile destroyer, the USS Chung-Hoon, to the South China Sea to protect the Impeccable on a surveillance operation. ${ }^{51}$ Apparently, the United States wanted to signal to China its resolve in continuing reconnaissance activities in China's EEZ. It was a rational decision for the United States given its much stronger naval power compared to China's. In response, Hu could have made a risky decision to send Chinese naval ships to the same area to counter U.S. provocative actions, or he could have avoided the risks and ignored U.S. surveillance activities in China's EEZ. In reality, Hu chose a middle-ground policy after the Impeccable incident.

On 15 March, China announced that it would send its largest fishery administrative ship, not a warship, to the same region and emphasized that the administrative ship was there to safeguard the country's maritime rights and enhance fishery protection in the EEZ in the South China Sea. As the China Daily reported, China could have sent monitoring vessels or even warships but instead exercised moderation by sending a fishery ship to the region after the Impeccable incident. ${ }^{52}$ By sending the fishery ship, China signaled its uncompromising position against U.S. surveillance in the EEZ zone but, at the same time, avoided direct military conflicts with U.S. naval ships.

Because Hu was framed in a domain of gains, an accommodative policy was chosen even after the provocative U.S. action of sending the Chung-Hoon to the EEZ following the Impeccable incident, which ended with the status quo, under which the United States continued surveillance and reconnaissance activities in China’s EEZ. China occasionally intercepts U.S. 
missions with its vessels and jet fighters. It is reported that unfriendly encounters between U.S. surveillance ships and Chinese vessels continued after the Impeccable incident, although the intensity of the confrontations was much lower. ${ }^{53}$ If the United States and China cannot reach an agreement to regulate their naval conduct in the sea, the danger of direct confrontation remains on the horizon. If future Chinese leaders are framed in a domain of losses, another Impeccable incident may end differently, maybe with violence.

\section{Case 2: The 2010 China-Japan “Boat Collision” Crisis}

The 2010 boat collision crisis between China and Japan happened on 7 September, when a Chinese fishing trawler collided with two Japanese Coast Guard (JCG) ships near the Diaoyu/Senkaku Islands. The JCG detained 15 Chinese fishermen and the trawler. The Chinese Foreign Ministry lodged a diplomatic protest against the Japanese action and demanded the immediate release of the crew members and assurance of the ship’s safety. In return, Japan called the Chinese Embassy in Tokyo to protest the actions of the Chinese ship. Japanese authorities stated that the Chinese ship had been conducting illegal fishing activities in Japanese waters and that Japan's actions had been based on Japanese law. In addition, Japan accused the Chinese ship of directly causing the collision. On 10 September, the JCG handed over the Chinese captain of the ship, Zhan Qixiong, to prosecutors for further investigation. The crisis escalated.

The dispute over the Diaoyu/Senkaku Islands between China and Japan originated in the early 1970s. Both China and Japan claimed sovereignty over the islands. After World War II, the Diaoyu/Senkaku Islands were administered by the United States under a United Nations trusteeship. In June 1971, the United States and Japan signed the Okinawa Reversion Agreement, which returned Okinawa and the Diaoyu/Senkaku Islands to Japan in 1972. On 30 December 
1971, before the United States officially returned Okinawa and the Diaoyu/Senkaku Islands to Japan, the Chinese Foreign Ministry announced that the islands were "an integral part of the Chinese territory," and therefore the U.S. action was illegal. ${ }^{54}$

For the sake of establishing diplomatic relations with Japan, Deng Xiaoping decided to "shelve" the dispute with Japan in 1972. Since then, the Diaoyu/Senkaku Islands have been administered and controlled by Japan, although China has never given up its sovereignty claims. The Diaoyu/Senkaku Islands are a traditional fishing area for fishermen from mainland China, Taiwan, and Hong Kong. In 1996, Japan drew an EEZ around the Diaoyu/Senkaku Islands to protect Japanese fishermen's fishing rights. However, the Chinese government never recognized Japan's sovereignty over the islands or the legitimacy of the EEZ. Consequently, fishing disputes occasionally have occurred between Chinese fishermen and the JCG. Despite the 1997 fishery agreement that China and Japan signed, different interpretations of the agreement caused even more problems. Normally, the JCG would block or chase away Chinese fishing boats that it thought were fishing illegally in Japanese waters. In 2008, a JCG vessel crashed and sunk a Taiwanese sport-fishing boat near the Diaoyu/Senkaku Islands.

When a fishing dispute occurs, the Chinese government normally lodges diplomatic protests and reiterates its indisputable sovereignty over the islands. The JCG normally blocks "illegal" activities, including landing on the islands and fishing. If it has to arrest some activists or fishermen, Japan typically releases or deports them soon afterward. Following the 2008 Taiwan boat collision, Japan apologized to the fisherman and offered financial compensation for the loss of his boat. ${ }^{55}$ However, the 2010 boat collision crisis did not follow this common practice in two respects. 
First, it is not clear why the JCG tried to block and chase away the Chinese ship. As a Wall Street Journal editorial pointed out, because the “1997 fishery agreement allows both sides' fishermen to operate free of regulation around the islands . . . it's not clear why the Japanese coast guard needed to stop the Chinese boat." ${ }^{56}$ Second, Japan not only arrested the crew but also transferred the Chinese captain to a prosecutor for investigation. Moreover, Japan threatened to use its domestic law to make charges against the Chinese captain for the collision. For China, the collision became a diplomatic crisis when Japan threatened to use its domestic laws to prosecute the Chinese captain. If China allowed that to happen, it would indicate that China officially admitted that the disputed Diaoyu/Senkaku Islands belonged to Japan.

Chinese top decision makers, including $\mathrm{Hu}$, had two options. First, Hu could continue doing what China had always done: lodging diplomatic protests and emphasizing sovereignty over the Diaoyu/Senkaku Islands without substantial actions. This is an accommodation policy that leaves open the possibility of releasing the Chinese captain to the Japanese government. The Chinese captain may not have been released and may not even have been charged under Japanese law. However, because the Chinese government insisted on sovereignty through diplomacy, it would not change the status quo of the situation, at least from the Chinese perspective. In other words, China would not give up its claim, and Japan would continue to control the islands. This accommodation policy would avoid further escalation of the crisis and preserve overall China-Japan relations.

The other option would be to choose coercive actions, diplomatically and even militarily, to force Japan to release the captain. This may have led to the quick release of the captain, but it could also have escalated the crisis and even damaged other aspects of China-Japan relations. If Japan refused to compromise, Chinese leaders, especially Hu, could face even greater domestic 
costs and international pressures. Because the risk of the action is measured by the possibility of conflict, the coercive action is much more risky than the accommodation option.

Hu's domain of action: Constrained publics and uneasy foreigners. Compared to the Impeccable incident, the severity of the boat collision crisis was relatively high because 15 Chinese crew members were detained by the Japanese authority. Although there were no casualties involved, the hostage situation intensified the severity of the crisis. Moreover, the Japanese government's threat to charge the captain under Japan's domestic laws further complicated the political sensitivity of the crisis. Japan's insistence on domestic laws was seen as a political plot to legitimatize its sovereignty over the disputed Diaoyu/Senkaku Islands in the eyes of Chinese decision makers.

Domestically, Hu's leadership authority within the CCP remained strong during the boat collision incident. Although Jiang's influence was still a political challenge for $\mathrm{Hu}, \mathrm{Hu}$ had successfully managed to promote his close associates to key positions from late 2009 to 2010. In addition, Hu had engaged in a "skirmish" with Jiang through the anticorruption campaign against the “Guangdong Gang” in 2009, during which three ministerial-level and several semiministerial-level officials were detained. As Guoguang Wu points out, few believed that the anticorruption campaign was based “purely on anti-corruption motives uncontaminated by power struggle.” Instead, it was Hu’s strategy to “weaken some Jiang protégés and support a forthcoming national leadership with a majority of Hu’s men” at the 18th Party Congress in 2012. ${ }^{57}$

However, Jiang was not ready to accept his political defeat in the CCP. Despite his retirement in 2004, he appeared on national television during the national parade for the sixtieth anniversary of the People’s Republic of China in 2009 and the 2010 Chinese New Year. It was 
definitely a reminder to Hu and others of Jiang's continuing influence within the CCP. With Jiang’s support, Xi Jinping, instead of Li Keqing—Hu’s longtime associate- - was appointed to succeed $\mathrm{Hu}$ at the 2012 Party Congress. Obviously, the power struggle between Hu and Jiang over personnel arrangements of the next generation of Chinese leadership loomed large until the 18th Party Congress in November 2012.

Economically, China started to show strong recovery from the 2008 global recession. In the first half of 2010, China’s economic growth reached 11.1 percent. In addition, China passed Japan to become the second-largest economy in the world. ${ }^{58}$ Despite numerous challenges from different factions inside the CCP and angry publics in Chinese society, Hu had been able to take control of the situation and consolidate his authority when the boat collision incident took place in 2010.

In the international arena, Hu had a hard time dealing with foreign relations after the 2008 Olympic Games. U.S.-China relations deteriorated after Obama’s “honeymoon” visit to China in late 2009. China's relations with its neighboring states were strained as a result of either long-standing territorial disputes or human rights issues. North Korea’s provocations put China in a diplomatic dilemma internationally. Obama paid his first state visit to Beijing in November 2009. Both parties kept up “smiling faces” during the visit and issued a joint statement to respect “each other’s core interests.” However, soon after returning to Washington, Obama approved arms sales to Taiwan and met with the Dalai Lama in January 2010.

In the eyes of Chinese leaders, this was a political betrayal, as Taiwan and Tibet were seen as China’s “core interests,” which the United Stated had just agreed to respect. For the United States, however, Obama did what his predecessors had normally done-that is, selling weapons to Taiwan and meeting with the Dalai Lama during their presidencies. China not only 
protested the U.S. decisions but also threatened to punish U.S. companies involved in the arms sales to Taiwan. ${ }^{59}$ Although China did not act on its threats, its strong reaction was criticized as “assertive diplomacy” in international politics. ${ }^{60}$ In January 2010, the Google controversy further shadowed U.S.-China relations. The U.S. Internet giant Google threatened to pull out of China because of the Chinese government's regulation on self-censorship and a Chinese-originated hacking attack. ${ }^{61}$

In July 2010, two months before the boat collision incident, Secretary of State Clinton publicly challenged China's policy in the South China Sea at the annual ASEAN (Association of Southeast Asian Nations) Regional Forum (ARF) ${ }^{62}$ For the first time, Secretary Clinton listed the freedom of navigation in the South China Sea as a vital national interest of the United States and proposed a multilateral approach to solving the territorial disputes between China and some Southeast Asian countries. Given the context of increasing tensions in the South China Sea and China’s long-standing "bilateralism” in dealing with the South China Sea disputes, Clinton's remarks at the ARF were seen as a "direct attack" on China. Chinese foreign minister Yang Jiechi reacted angrily and stormed out of the meeting at the ARF.

As a longtime supporter of North Korea, China was put in an embarrassing situation in late 2009 and early 2010 by North Korea's provocations. During the power succession period of North Korea, Chinese leaders had frequent meetings with North Korean leader Kim Jong-il. After North Korea's second nuclear test in May and several missile tests in July 2009, Beijing tried hard to convince Pyongyang to stay in the Six-Party Talks. Dai Bingguo visited North Korea in September, and Premier Wen Jiabao met Kim Jong-il in Pyongyang in October 2009. After Wen provided a huge amount of financial aid, Kim conditionally agreed to return to the 
Six-Party Talks. ${ }^{63}$ However, soon after Wen returned to Beijing, North Korea tested five shortrange missiles. Wen's visit thus proved fruitless.

In March 2010, the Cheonan, a South Korean patrol vessel, was sunk by an unknown torpedo. South Korea and the United States accused North Korea of orchestrating the incident. Beijing did not join the United States in condemning North Korea for the Cheonan incident. Instead, China stated that it was "willing to continue communicating with relevant parties in pursuit of a proper settlement of the issue so as to avoid escalation of tension and maintain peace and stability on the Korean Peninsula." ${ }^{, 4}$ In order to deter North Korea's provocations, the United States conducted joint military exercises with South Korea, during which the United States intended to deploy the aircraft carrier USS George Washington near the area of the Cheonan incident in the Yellow Sea. China furiously opposed the U.S. deployment of an aircraft carrier near China’s coast in the Yellow Sea because it would “imperil China’s national security and provoke North Korea." 65

For the United States and South Korea, China's action was nothing but an endorsement of North Korea's provocations. It further deteriorated the strained relationship between China and the United States. Later, in November 2010, North Korea escalated the tension by shelling Yeonpyeong, a South Korean island near the disputed maritime border between the North and the South. China was embarrassed again, as it had failed to control its ally. North Korea, therefore, had become a diplomatic liability rather than leverage for China to improve its relations with the United States and its neighboring states.

In addition to the diplomatic tensions with the United States, China's relations with other regional powers were also suffering from late 2009 to the time of the boat collision incident in September 2010. For example, in July 2009, China lodged diplomatic protests with Australia and 
Japan for hosting Rebiya Kaeer, an exiled separatist from Xinjiang and an alleged terrorist according to the Chinese government. ${ }^{66}$ In early 2010, Vietnam protested against China's arrest of Vietnamese fishermen near the disputed Paracel Islands. ${ }^{67}$ Clinton’s statement at the ARF, as mentioned earlier, further inflamed the South China Sea disputes between China and its Southeast Asian neighbors, especially Vietnam and the Philippines, because in the eyes of Chinese policymakers, it was the first time the United States had become involved in the South China Sea disputes.

Hu's risk-acceptant policy: Coercive diplomacy toward Japan. In sum, the severity of the crisis and the harsh international environment framed $\mathrm{Hu}$ in a domain of losses when the boat collision incident took place in September 2010. The hostage situation plus the related "sovereignty" scheme of the Japanese government in prosecuting the Chinese captain intensified the severity of the crisis. Although Hu's domestic authority was consolidated during his second term, the high international pressure from deteriorating foreign relations with the United States and China's neighboring states framed $\mathrm{Hu}$ in a domain of losses. According to the political survival prospect model, Hu should have taken a risk-acceptant policy in dealing with the boat collision incident in order to reverse his disadvantageous situation, which was framed by high crisis severity and high international pressure. In reality, China adopted a series of diplomatic coercive actions toward Japan during the 17 days of the crisis. There were three types of coercive measures in China's strategy.

First, China gradually elevated the level of diplomatic protests. On 8 September, one day after the crisis, China’s assistant foreign minister called the Japanese ambassador to protest Japan's action and demand the release of the crew members and assurance of the ship's safety. In addition, on 9 September, Chinese Foreign Ministry spokesperson Jiang Yu told reporters that 
China had dispatched a fishery administrative ship to safeguard the activities of Chinese fishermen in the Diaoyu/Senkaku area. It was China's strategy to reiterate its historical sovereignty claim over the disputed islands. On 11 September, Dai Bingguo, in charge of China's foreign policy decision making in the State Council, called the Japanese ambassador again for a midnight meeting and urged Japan "not to make a wrong judgment on the situation.,

Seemingly, Dai’s pressure worked, but only halfway. On 13 September, Japan released the 14 crew members and returned the Chinese fishing ship but kept the Chinese captain in custody. On 14 September, a Chinese assistant foreign minister again called the Japanese ambassador to demand the immediate release of the captain. After the normal "10-day" bottom line of detention passed, China's vice foreign minister called the Japanese ambassador to make another protest. China's diplomatic coercion reached a peak when Premier Wen publicly criticized Japan's action and demanded the immediate and unconditional release of the Chinese captain during the United Nations General Assembly meeting in New York. Wen warned that if the Japanese side insisted on acting arbitrarily, the Chinese side would take new actions. Japan would have to take all of the responsibility for any serious consequences. ${ }^{69}$ It was rare for the Chinese premier to get directly involved in diplomatic issues, not to mention issuing a warning to Japan; therefore, it was a clear sign that the Chinese government took the detention of the Chinese captain seriously.

Second, China cancelled high-level bilateral meetings to protest Japan’s action. On 11 September, China announced the postponement of the scheduled mid-September round of negotiations on the joint development of natural resources in the East China Sea because of Japan's "illegal actions" during the boat collision incident. On 13 September, China cancelled a 
scheduled visit of Li Jianggu, vice chairman of the Standing Committee of the National People's Congress, to Japan. When Japan declared that it would extend the detention of the Chinese captain on 20 September, China announced the suspension of ministerial and high-level exchanges with Japan. On 21 September, Beijing also ruled out a summit meeting between Chinese premier Wen and Japanese prime minister Naoto Kan at the United Nations General Assembly in New York, which originally had been seen by Japan as a good opportunity to settle the crisis.

Finally, China applied various economic and social pressures on Japan. Economically, the Chinese government reportedly requested that state-owned travel agencies exercise restraint in organizing and publicizing tours to Japan. As China is the largest tourist origin for Japan, this “restraint” policy would hurt Japan’s tourist industry. In addition, the Chinese government cut the export of rare earth metals to Japan, the essential material for electronic products and hybrid cars, in an effort to increase pressure on the Japanese government. Although the Chinese Ministry of Commerce denied any link between the export restraint on rare earth metals and the boat collision, Japanese industry and government felt real economic pressure from China. ${ }^{70}$

On the societal front, the boat collision incident took place during a very sensitive time period, as it spanned the anniversary of the Manchurian Incident on 18 September 1931. The Manchurian Incident, or the September 18 Incident, is seen as the beginning of the Japanese invasion of China before World War II. The bitter historical memory plus a fresh diplomatic crisis ignited a strong anti-Japanese nationalist sentiment in China. Large-scale demonstrations and protests took place at the Japanese Embassy in Beijing as well as at the Consulates General in Shanghai and Shenyang. Because the Chinese government tried hard to control the situation, no injuries or property damages were reported. 
On 20 September, 13 days after the crisis, China arrested four Japanese nationals who worked for Fujita Construction in Shijiazhuang, Hebei Province, after they tried to "enter a restricted military area without permission.” This event was seen as a breaking point for the final settlement of the crisis. On 24 September, Japan's local prosecutor's office, which was in charge of investigating the boat collision incident, announced the immediate release of the Chinese captain because it was “inappropriate to detain any longer and continue investigations.” In addition, the local prosecutor's office explained that the decision was based on "considerations about the Japan-China relationship.”71 The Japanese government denied any role in releasing the Chinese captain and said that the decision had been made independently by the local prosecutors. It is still not clear why Japan released the Chinese captain after 17 days. Although the Japanese government denied any "horse trading” with China, the four Japanese nationals from Fujita were released by the Chinese government after the Chinese captain was returned to China. For the Chinese, it is also not clear why Japan decided to detain the captain and escalate the crisis in the first place. ${ }^{72}$ However, there is no doubt that China's coercive diplomacy toward Japan succeeded in settling the crisis. From the beginning to the end of the crisis, China's uncompromising position never changed. This coercive policy is a risk-acceptant choice for two reasons.

First, China’s coercive diplomacy seriously damaged bilateral relations between China and Japan. Although the possibility of military conflict was remote, it is apparent that the deterioration of bilateral relations may breed future conflicts over the Diaoyu/Senkaku Islands. The consequences can be seen in the later "purchase of the Diaoyu/Senkakus" crisis in 2012. Second, Chinese leaders, especially President Hu and Premier Wen, faced huge domestic audience costs that they would have had to pay if they had backed down in the crisis. The stakes 
of continuous escalation of the crisis were high for the Chinese leadership because of surging nationalism during the sensitive time of the anniversary of the Manchurian incident in China. If Hu had not settled the crisis swiftly and successfully, he and other Chinese leaders would have faced political punishment from their political adversaries and social groups.

During a personal interview conducted by this author in July 2012 in Beijing, a leading Chinese international relations expert with close connections to the Chinese government described Hu’s policy dilemma during the crisis as “riding a tiger.” On the one hand, Hu had no choice but to maintain the coercive policies toward Japan during the crisis because he would have faced higher political costs otherwise. To a certain extent, Chinese leaders had been hijacked by the situation. On the other hand, Hu was also frustrated by the ineffective coercive measures toward Japan. Even after Wen’s rare but serious threat, the situation did not improve. It was like a vicious circle. The seemingly ineffective action drove the Chinese leaders into an even more embarrassing situation. The larger diplomatic embarrassment, in turn, led to more coercive actions.

As mentioned earlier, the breaking point was China’s arrest of four Japanese nationals on 20 September on possible espionage charges. It was reported that it was a coincidence during which the four Japanese nationals had an unpleasant encounter with the local military officials. When this event was reported to the higher authority in Beijing, the central government seized the opportunity to use the event as diplomatic leverage against Japan in coping with the boat collision crisis. It is reported that the local military officers were promoted after the boat collision incident was settled because of their high "political sensitivity."73

As to why Japan compromised in the crisis, it is still not clear and beyond the scope of this research. However, the political survival prospect model may shed some light on explaining 
Japanese leaders' decisions during the crisis. Counterfactually, if Japan did not compromise, Hu and the Chinese leadership would have borne all the costs associated with China's risk-acceptant diplomatic coercions. Diplomatically, China-Japan relations would have deteriorated.

Domestically, anti-Japanese nationalist sentiments would have turned anger toward the Chinese government and may even have challenged the political legitimacy of the communist regime. To a certain extent, Hu and the Chinese leadership were lucky in resolving the boat collision crisis, with Japan eventually backing down. However, this does not mean that China's risk-acceptant decisions will always pay off in the future. Policymakers will need to seriously consider how to avoid a stalemate and shape leaders' domains of action during foreign policy crises in the future.

\section{CONCLUSION}

This article has examined why Chinese president Hu Jintao chose to compromise with the United States during the 2009 Impeccable incident but conducted coercive policies toward Japan during the 2010 boat collision crisis. One simple explanation may be that China had to compromise because of the power disparity under the U.S. unipolar system, whereas it did not need to do the same for Japan, which was relatively weaker than a rising China. ${ }^{74}$ This realist explanation is problematic for two reasons. First, China had fought with the United States when it was much weaker in Korea. Even after the Cold War, the escalation of the 1995-1996 Taiwan crisis also indicated that China would not easily compromise in response to U.S. pressure. Second, although Japan's economy was relatively declining in comparison to China's, its military capabilities remained the most modern in East Asia. As some commentators have pointed out, Japan has been supplied with advanced military equipment from the United States for decades, while the majority of Chinese weapons systems are in various stages of decay. More importantly, the U.S.- 
Japan military alliance significantly alters the military balance between China and Japan. ${ }^{75}$ Therefore, it is difficult to conclude that Japan is weak militarily in comparison to China in conflicts over territorial disputes.

Borrowing insights from prospect theory, this article introduced a political survival prospect model of crisis behavior to explain Hu's policy decisions during these two crises. It suggests that Hu adopted a risk-averse policy to accommodate and defuse the diplomatic tension with the United States because “everything is getting right” for $\mathrm{Hu}$ in both the domestic and international arenas. During the boat collision crisis with the Japan, Hu was placed in a domain of losses because of the high crisis severity and high international pressure. Therefore, Hu chose a risk-acceptant policy—a series of diplomatic coercions against Japan in the crisis.

This research contributes to the study of foreign policy crisis behavior in three aspects. First, this article applies the political survival prospect model to explain China's crisis behavior under Hu. It is interesting to see how this model can be used to account for policy variations of other leaders, such as Jiang Zemin and Xi Jinping. More importantly, the political survival prospect model can be applied to foreign policy crisis behavior of other countries. For example, why Japan chose a risk-acceptant policy at the beginning of the boat collision crisis but later changed to a risk-averse policy by releasing the Chinese captain is an interesting research question to test the validity of the model.

Second, China experienced a once-a-decade leadership transition in 2012. The new Chinese president Xi Jinping will need some time to consolidate his leadership authority in the CCP. During the power consolidation period, Xi will be more vulnerable to the influence and pressures of the military and the outside world if foreign policy crises occur. Consequently, Xi may adopt risk-acceptant policies as a political tool to establish his authority in the CCP. It is 
widely believed that Xi was one of the key decision makers handling the two foreign policy crises that China experienced in 2012: the Scarborough shoal dispute with the Philippines and the Senkaku/Diaoyu purchase crisis with Japan. ${ }^{76}$ If this is the case, then the political survival prospect model can explain why China adopted strong coercive diplomacies in both cases.

Finally, other states, especially the United States, should pay more attention to Chinese leaders' domain of actions during foreign policy crises. In order to avoid China’s risk-acceptant behavior during crises, other states need to carefully consider shaping and altering Chinese leaders' domain of actions. On the one hand, active people-to-people diplomacy is important for other countries to construct positive images and perceptions among the Chinese public. Public opinion has played an increasing role in influencing Chinese decision makers' domains of actions. On the other hand, a constructive bilateral relationship with China is a key brake to keep Chinese leaders out of the domain of losses during crises. Diplomatic successes have become an important instrument for Chinese leaders to consolidate their authority at home. How to utilize diplomatic means to influence Chinese leaders' domain of actions, especially during crises, will be a tough task for U.S. policymakers in dealing with a rising China in the twenty-first century.

\section{Endnotes}

${ }^{1}$ For an official statement on the United States' “pivot to Asia,” see Hillary Clinton, “America’s Pacific Century,” Foreign Policy 189 (November 2011): 56-63.

${ }^{2}$ Michael Brecher and Jonathan Wilkenfeld, A Study of Crisis (Ann Arbor: University of Michigan Press, 2000), 3.

${ }^{3}$ Patrick James, cited by Jonathan Wilkenfeld in "Concepts and Methods in the Study of International Crisis Management,” in Michael D. Swaine and Zhang Tuosheng, eds., Managing 
Sino-American Crises: Case Studies and Analysis (Washington, DC: Carnegie Endowment for International Peace, 2006), 111.

${ }^{4}$ Andrew Scobell and Larry Wortzel, eds., Chinese National Security: Decisionmaking under Stress (Carlisle, PA: U.S. Army War College, Strategic Studies Institute, 2005), 1.

${ }^{5}$ International Crisis Group, “Stirring up the South China Sea (II): Regional Responses,” Asia Report, no. 229 (24 July 2012).

${ }^{6}$ Wu Xinbo, Managing Crisis and Sustaining Peace between China and the United States (Washington, DC: United States Institute of Peace, 2008); Wang Jisi and Xu Hui, "Pattern of Sino-American Crises: A Chinese Perspective," in Swaine and Zhang, eds., Managing SinoAmerican Crises, 133-148.

${ }^{7}$ Leading scholars from the United States and China worked together to examine the onset, escalation, and management of political and military crises between the United States and China from 1949 to 2004. This study is the most comprehensive analysis of China's foreign policy crises so far. More importantly, this project explores differences as well as similarities between the Chinese and American scholars in their understanding of foreign policy crises. The book was published in 2006. See Swaine and Zhang, eds., Managing Sino-American Crises: Case Studies and Analysis.

${ }^{8}$ Michael D. Swaine, “Understanding the Historical Record,” in Swaine and Zhang, eds., Managing Sino-American Crises: Case Studies and Analysis, 1-69, at 10.

${ }^{9}$ Thomas J. Christensen, Useful Adversaries: Grand Strategies, Domestic Mobilization, and Sino-American Conflict, 1947-1958 (Princeton, NJ: Princeton University Press, 1996). For other examples, see M. Taylor Fravel, Strong Borders, Secure Nation: Cooperation and Conflict in China's Territorial Disputes (Princeton, NJ: Princeton University Press, 2008). 
${ }^{10}$ Allen Whiting, China Crosses the Yalu: The Decision to Enter the Korean War (Stanford, CA: Stanford University Press, 1968).

${ }^{11}$ Brecher and Wilkenfeld, A Study of Crisis, 841.

${ }^{12}$ Wang and Xu, "Pattern of Sino-American Crises," 138.

${ }^{13}$ For a general audience cost argument, see James D. Fearon, “Domestic Political Audiences and the Escalation of International Disputes," American Political Science Review 88 (September 1994): 577-592; Fearon, "Signaling Foreign Policy Interests: Tying Hands versus Sinking Cost,” Journal of Conflict Resolution 41 (February 1997): 68-90; Jessica L. Weeks, “Autocratic Audience Costs: Regime Type and Signaling Resolve,” International Organization 62 (January 2008): 35-64; and Jessica Chen Weiss, “Autocratic Signaling, Mass Audiences, and Nationalist Protest in China,” International Organization 67 (January 2013): 1-35. For critiques of audience cost theory, see Jack Snyder and Erica D. Borghard, "The Cost of Empty Threats: A Penny, Not a Pound,” American Political Science Review 105 (August 2011): 437-456; and Marc Trachtenberg, “Audience Costs: An Historical Analysis,” Security Studies 21(February 2012): 342.

${ }^{14}$ Weiss, “Autocratic Signaling.”

${ }^{15}$ For bounded rationality, see Herbert A. Simon, Models of Man: Social and Rational;

Mathematical Essays on Rational and Human Behavior in a Social Setting (New York: Wiley, 1957).

${ }^{16}$ For the information problem, see Thomas C. Schelling, The Strategy of Conflict (Cambridge, MA: Harvard University Press, 1960); and James D. Fearon, "Rationalist Explanations for War,” International Organization 49 (Summer 1995): 379-414. 
${ }^{17}$ See Dennis C. Blair and David B. Bonfili, “The April 2001 EP-3 Incident: The U.S. Point of View,” in Swaine and Zhang, eds., Managing Sino-American Crises, 377-389.

${ }^{18}$ See Wu, "Understanding Chinese and U.S. Crisis Behavior”; and Wu, Managing Crisis and Sustaining Peace.

${ }^{19}$ Wang and Xu, "Pattern of Sino-American Crises," 141-142. For a similar cultural perspective, see Chih-Yu Shih, China’s Just World: The Morality of Chinese Foreign Policy (Boulder, CO: Lynne Rienner, 1993).

${ }^{20}$ See Alastair Iain Johnston, Cultural Realism: Strategic Culture and Grand Strategy in Chinese History (Princeton, NJ: Princeton University Press, 1995); and Johnston, “Cultural Realism and Strategy in Maoist China," in Peter J. Katzenstein, ed., The Culture of National Security: Norms and Identity in World Politics (New York: Columbia University Press, 1996), 216-270. For a different view of China's strategic culture, see Huiyun Feng, Chinese Strategic Culture and Foreign Policy Decision-Making: Confucianism, Leadership and War (New York: Routledge, 2007).

${ }^{21}$ See Swaine and Zhang, eds., Managing Sino-American Crises, 13-14.

${ }^{22}$ Daniel Kahneman and Amos Tversky, "Prospect Theory: An Analysis of Decision under Risk,” Econometrica 47 (March 1979), 263-291. Tversky died in 1996, and Kahneman was awarded the 2002 Nobel Prize in economics for his work in prospect theory. ${ }^{23}$ Rose McDermott, "Prospect Theory in Political Science: Gains and Losses from the First Decade,” Political Psychology 25 (April 2004): 289-312, at 294.

${ }^{24}$ Prospect theory has other interesting findings, such as the endowment effect and loss aversion. In this article, I focus on the framing effect, that is, how the domains of action with respect to the reference point influence risk propensity and behavior. For discussions of other findings of 
prospect theory, see Jack S. Levy, "Prospect Theory and International Relations: Theoretical Applications and Analytical Problems,” in Barbara Farnham, ed., Avoiding Losses/Taking Risks: Prospect Theory and International Conflict (Ann Arbor: University of Michigan Press, 1995), 119-146; Robert Jervis, “Political Implications of Loss Aversion,” Political Psychology 13 (June 1992): 187-201; Jervis, “The Implications of Prospect Theory for Human Nature and Values,” Political Psychology 25 (April 2004): 163-176; and Barry O’Neill, “Risk Aversion in International Relations Theory,” International Studies Quarterly 45 (December 2001): 617-640. ${ }^{25}$ See Milton Friedman, “The Methodology of Positive Rationality,” in Milton Friedman, ed., Essays in Positive Economics (Chicago: University of Chicago Press, 1957), 3-43; and Farnham, Avoiding Losses/Taking Risks. For a comprehensive critique of rational choice approaches, see Donald P. Green and Ian Shapiro, Pathologies of Rational Choice Theory: A Critique of Applications in Political Science (New Haven, CT: Yale University Press, 1994).

${ }^{26}$ Insurance and gambling are two prominent examples of anomalies of expected utility theory in everyday life. For a discussion, see Jack S. Levy, “An Introduction to Prospect Theory,” in Farnham, ed., Avoiding Losses/Taking Risks, 7-22, at 10-11.

${ }^{27}$ For example, see Farnham, Avoiding Losses/Taking Risks; Rose McDermott, Risk-Taking in International Relations: Prospect Theory in Post-War American Foreign Policy (Ann Arbor: University of Michigan Press, 1998); Jeffrey W. Taliaferro, Balancing Risks: Great Power Intervention in the Periphery (Ithaca, NY: Cornell University Press, 2004); Jonathan Mercer, “Prospect Theory and Political Science,” Annual Review Political Science 8 (June 2005): 1-21; Steve Chan, China, the U.S. and the Power-Transition Theory: A Critique (New York: Routledge, 2007); and Thomas J. Christensen, “The Meaning of the Nuclear Evolution: China’s 
Strategic Modernization and U.S.-China Security Relations,” Journal of Strategic Studies 35 (August 2012): 447-487.

${ }^{28}$ Alexander George, “Strategies for Crisis Management,” in Alexander George, ed., Avoiding War: Problems of Crisis Management (Boulder, CO: Westview Press, 1991), 378.

${ }^{29}$ For a criticism on the lack of a theory of framing, see Jack S. Levy, "Prospect Theory, Rational Choice, and International Relations,” International Studies Quarterly 41 (March 1997): $87-112$.

${ }^{30}$ Mercer, "Prospect Theory and Political Science," 4.

${ }^{31}$ Bruce Bueno de Mesquita, Alastair Smith, Randolph M. Siverson, and James D. Morrow, The Logic of Political Survival (Cambridge, MA: MIT Press, 2003).

${ }^{32}$ See Susan Shirk, The Political Logic of Economic Reform in China (Berkeley: University of California Press, 1993); and Bruce Bueno de Mesquita, James D. Morrow, Randolph M.

Siverson, and Alastair Smith, “An Institutional Explanation of the Democratic Peace,” American Political Science Review 93 (December 1999): 791-807.

${ }^{33}$ Steven David, “Explaining Third World Alignment,” World Politics 43 (January 1991): 233256.

${ }^{34}$ M. Taylor Fravel, “Regime Insecurity and International Cooperation: Explaining China’s Compromise in Territorial Disputes," International Security 30 (March 1995): 46-83.

${ }^{35}$ David Morgan, “U.S. Says Chinese Vessels Harassed Navy Ship,” Reuters, 9 March 2009; see also Tony Capaccio, “Chinese Vessels Harass U.S. Navy ship, Pentagon Says,” Bloomberg News, 9 March 2009.

${ }^{36}$ CNN, “Pentagon Says Chinese Vessels Harassed U.S. Ship,” accessed at http://www.cnn.com/2009/politics/0309/us.navy.china/index.html, 6 June 2010. 
${ }^{37}$ Xinhua, “China Says U.S. Naval Ship Breaks International, Chinese Law,” 10 March 2009, accessed at http://www.china-embassy.org/eng/zmgx/t541599.htm, June 6 2010; see also BBC News, “China Hits out at U.S. on Navy Row,” 10 March 2009, accessed at http://news.bbc.co.uk/2/hi/asia-pacific/7934138.stm, 6 June 2010.

${ }^{38}$ Ji Guoxing, “The Legality of the 'Impeccable Incident,'” China Security 5 (Spring 2009): 1924.

${ }^{39}$ Ann Scott Tyson, “China Draws U.S. Protest over Shadowing of Ships,” Washington Post, 10 March 2009.

${ }^{40}$ Lei Zhihua, "Mei guofangbu cheng zhongguo chuanzhi zai nanzhongguo hai genzong meijun celiangchuan” [Pentagon reports Chinese ships chasing U.S. surveillance vessel], Huaqiu Shibao [Global times], 10 March 2009.

${ }^{41}$ Oriana Skylar Mastro, "Signaling and Military Provocation in Chinese National Security Strategy: A Closer Look at the Impeccable Incident,” Journal of Strategic Studies 34 (April 2011): 219-244.

${ }^{42}$ For these “incidental encounters,” see Bernard Cole, “Beijing Strategy of Sea Denial,” China Brief 6 (2007); and Jonathan Kent, “U.S. Warns on China Sub Encounter,” BBC News, 14 November 2006, accessed at http://news.bbc.co.uk/2/hi/asia-pacific/6146520.stm, 11 October 2015.

${ }^{43}$ Joseph Fewsmith, China since Tiananmen: From Deng Xiaoping to Hu Jintao, 2nd ed. (New York: Cambridge University Press, 2008), 270.

${ }^{44}$ Chen was arrested because of his involvement in a pension fund scandal. He was later sentenced to 18 years in prison on charges of financial fraud, abuse of power, and accepting bribes. 
${ }^{45}$ David Barboza, “China Plans \$586 Billion Economic Stimulus,” New York Times, 9

November 2008.

${ }^{46}$ Yuan Peng, “Aobaoma Zhenfu Duihua Zhengce yu Zhongmei Guanxi Weilia” [Obama’s China policy and the future of U.S.-China relations], Guoji Zhanwang [International outlook] 3 (2009): 4-7.

${ }^{47}$ See Bonnie Glaser, “A Good Beginning Is Half Way to Success,” Comparative Connections 11 (April 2009): 25-36.

${ }^{48}$ See Peter Baker, “Obama Calls for Military Dialogue with China” New York Times, 12 March 2009; and Glaser, “A Good Beginning Is Half Way to Success.”

${ }^{49}$ Cited by Glaser, “A Good Beginning Is Half Way to Success.”

${ }^{50}$ For an analysis of China’s media campaign, see Mastro, "Signaling and Military Provocation in Chinese National Security Strategy.”

${ }^{51}$ Ann Scott Tyson, "Navy Sends Destroyer to Protect Surveillance Ship after Incident in South China Sea,” Washington Post, 13 March 2009.

52 Lan Tian, “Fishery Patrol Ship Sent to Protect Interests,” China Daily, 16 March 2009.

${ }^{53}$ For other encounters after the Impeccable incident, see Shirley A. Kan, “U.S.-China Military Contacts: Issues for Congress” (Report RL32496, Congressional Research Service, Washington, DC, 27 October 2012), 68-69.

${ }^{54}$ For the Chinese position, see State Council Information Office, “Diaoyu Dao, an Inherent Territory of China,” China’s State Council Information Office, September 2012; for the Japanese official position, see Ministry of Foreign Affairs of Japan, “Japan-China Relations: Current Situation of Senkaku Islands,” accessed at http://www.mofa.go.jp/region/asiapaci/senkaku/index.html, 6 June 2014. 
55 “Japan Apologizes over Taiwan Boat Incident,” China Post, 20 June 2008, accessed at http://www.chinapost.com.tw/taiwan/foreign-affairs/2008/06/21/161947/Japan-apologizes.htm, 6 June 2014.

56 “The Other China Sea Flashpoint: Japan Risks Unleashing the Genie of Chinese Nationalism,” Wall Street Journal, 12 September 2010.

${ }^{57}$ Guoguang Wu, “China in 2009: Muddling through Crises,” Asian Survey 50 (January/February 2010): 25-39, at 35 .

${ }^{58}$ David Barboza, “China Passes Japan as Second-Largest Economy,” New York Times, 12 August 2010.

${ }^{59}$ Helene Cooper, “U.S. Approval of Taiwan Arms Sales Angers China,” New York Times, 30 January 2010; see also Keith Bradsher, “U.S. Deal with Taiwan Has China Retaliating,” New York Times, 31 January 2010.

${ }^{60}$ For an excellent review of the perceptions of China's assertiveness, see Michael Swaine, “Perceptions of an Assertive China,” China Leadership Monitor 32 (May 2010): 1-19; Swaine, “China’s Assertive Behavior-Part One: One 'Core Interests,'” China Leadership Monitor 34 (February 2011): 1-30; and Swaine and M. Taylor Fravel, “China’s Assertive Behavior-Part Two: The Maritime Periphery,” China Leadership Monitor 35 (September 2011): 1-29. For China’s assertiveness in the South China Sea, see Jane Perlez, “Beijing’s Exhibiting New Assertiveness in South China Sea,” New York Times, 31 May 2012.

${ }^{61}$ Ben Worthen, “Researchers Say Up to 100 Victims in Google Attack,” Wall Street Journal, 26 February 2010.

${ }^{62}$ Gordon Chang, “Hillary Clinton Changes American’s China Policy,” Forbes, 28 July 2010. 
${ }^{63}$ Peter Ford, “North Korea Ready for Six-Party Talks-With Caveat,” Christian Science Monitor, 6 October 2009.

${ }^{64}$ Foreign Ministry spokesperson Qin Gang, press conference, June 29, 2010, accessed at http://www.fmprc.gov.cn/eng/xwfw/s2510/t712798.htm, 6 June 2014.

${ }^{65}$ Andrew Browne and Evan Ramstad, “U.S.-South Korea Exercises Rile China,” Wall Street Journal, 20 August 2010.

${ }^{66}$ Ying Wenshi, “Who Provide Stage for Rebiya Kadeer?,” Xinhua News Agency, 13 August 2009.

67 “Vietnam Accuses China in Seas Disputes,” BBC News, 30 May 2011, accessed at http://www.bbc.com/news/world-asia-pacific-13592508, 11 October 2015.

${ }^{68}$ For China’s detailed actions after the boat collision incident, see James Przystup, “Troubled Waters,” Comparative Connections 12 (October 2010): 101-114; the boat collision incident news collection by Hong Kong Phoenix TV, accessed at http://www.ifeng.com/opinion/special/zhongridiaoyudao, 6 June 2014; Zhang Yong, “Diaoyudao Shijian yu Minzhu Dang zhengfu de duihua waijiao” [Diaoyudao incident and Japanese Democratic Party’s China diplomacy], in Li Wei, ed., Riben Fazhan Baogao [Japan development report 2011] (Beijing: Social Sciences Academic Press, 2011), chap. 14.

${ }^{69}$ Wu Jiao, “Premier Wen Urges Japan to Release Captain,” China Daily, 22 September 2010.

${ }^{70}$ Mari Yamaguchi, “China Rare Earth Exports to Japan still Halted,” Businessweek, 21 October 2010.

${ }^{71}$ Martin Fackler and Ian Johnson, “Japan Retreats with Release of Chinese Boat Captain,” New York Times, 24 September 2010. 
${ }^{72}$ Some Chinese analysts attributed the boat collision incident to the dynamics of Japan's domestic politics, especially the election of the Japanese Democratic Party on 14 September during the crisis. See Liu Jiangyong, "Bolan qifu de 2010 nian zhongri guanxi” [The dynamics of China-Japan relations in 2010], in Li Wei, ed., Riben Fazhan Baogao, chap. 6.

${ }^{73}$ The author's personal interview in Beijing, July 2012.

${ }^{74}$ The author thanks anonymous reviewers who suggested this rival explanation.

${ }^{75}$ See Jeremy Bender and Gus Lubin, “Why Japan’s Smaller Military Could Hold Its Own against China,” Business Insider, 5 May 2014, accessed at http://www.businessinsider.com/japans-smaller-military-could-match-china-2014-5, 6 June 2014.

${ }^{76}$ Linda Jakobson, “How Involved Is Xi Jinping in the Diaoyu Crisis,” The Diplomat, 8 February 2013; see also International Crisis Group, “Dangerous Waters: China-Japan Relations on the Rocks,” Asia Report, no. 245 (8 April 2013). 